\title{
Seismicity in the Antarctic Continent and Surrounding Ocean
}

\author{
Masaki Kanao \\ National Institute of Polar Research, Midori-cho, Tachikawa-shi, Tokyo, Japan \\ Email: kanao@nipr.ac.jp
}

Received November 18, 2013; revised December 20, 2013; accepted January 27, 2014

\begin{abstract}
Copyright (C) 2014 Masaki Kanao. This is an open access article distributed under the Creative Commons Attribution License, which permits unrestricted use, distribution, and reproduction in any medium, provided the original work is properly cited. In accordance of the Creative Commons Attribution License all Copyrights (C) 2014 are reserved for SCIRP and the owner of the intellectual property Masaki Kanao. All Copyright (C) 2014 are guarded by law and by SCIRP as a guardian.
\end{abstract}

\section{ABSTRACT}

Seismicity in the Antarctic and surrounding ocean is evaluated based on the compiling data by the International Seismological Centre (ISC). The Antarctic continent and surrounding ocean have been believed to be one of the aseismic regions of the Earth for many decades. However, according to the development of Global Seismic Networks and local seismic arrays, the number of tectonic earthquakes detected in and around the Antarctic continent has been increased. A total of 13 seismicity areas are classified into the Antarctic continent ( 3 areas) and oceanic regions within the Antarctic Plate (10 areas). In general, seismic activity in the continental areas is very low in Antarctica. However, a few small earthquakes are identified. Wilkes Land in East Antarctica is the most tectonically active area in the continent, with several small earthquake events having been detected during the last four decades. In the oceanic region, in contrast, seismic activity in the area of $120^{\circ}-60^{\circ} \mathrm{W}$ sector is three times higher than that in the other oceanic areas. This may be considered to be involved in a tectonic stress concentration toward the Easter Island Triple Junction between the Antarctic Plate, the Pacific Plate and the Nazuca micro-Plate. Three volcanic areas, moreover, the Deception Island, the Mts. Erebus and Melbourn, are also found to be high seismic activities in contrast with surrounding vicinity areas.

\section{KEYWORDS}

\section{Seismicity; Antarctic Plate; Antarctic Continent; Southern Ocean; Tectonic Stress}

\section{Introduction}

The Antarctic Plate has a unique tectonic setting that it is surrounded by almost completely divergent margins, with a very small amount of convergent or transformed margins. The divergent margins are characterized by the circum Antarctic seismic zones and cover about 92\% of the surroundings of the Antarctic Plate. The convergent margins locate in the northwestern part of the South Shetland Islands and are less than $2 \%$ of the plate boundary. The transformed margins cover less than $7 \%$ along the boundary of the Scotia micro-Plate (Figure 1).

Seismicity in the Antarctic Plate is not so high compared with other plates. However, the seismicity becomes gradually clear in the last few decades by the development of Global Seismic Networks as well as the local seismic stations deployed in the Antarctic. It was a general knowledge by 1957, when the International Geo- physical Year (IGY) started, that the seismic activity in the Antarctic continent was very low and only minor activity in the vicinity of active volcano, such as the Mount Erebus, was to be expected [1,2]. One of the other active volcanoes, the Deception Island in the South Shetland Islands was already known since the $19^{\text {th }}$ century, but no seismic observation was carried out in the Island until the IGY. During the IGY period, ten seismic stations were established in the Antarctic and arrival time information on seismic phases recorded at the deployed stations had been reported to the United States Coastal Geological Survey (USGS), significantly contributed to the determination of earthquake locations globally. However, no earthquakes were determined by their hypocenters in the Antarctic at the time. USCGS had published "Antarctic Seismological Bulletin" based on travel time information received telegraphically from the Antarctic seismic sta- 
tions during 15 years since IGY.

As the number of seismic stations in the Antarctic has been increased, local and regional earthquakes came to be detected within the Antarctic continent, even though their seismic activities were very low $[3,4]$. It became clear that an earthquake with magnitude around 4 occurred every few years in the Antarctic continent. However, no earthquakes with magnitude larger than 5 have occurred during the last four decades. [5] proposed an explanation for the lack of seismic activity of the Antarctic continent in terms of loading effects by overlying continental ice sheet. As the number of seismic stations of the globe increased, several tectonic earthquakes have been detected in the Antarctic. Inside the Southern Ocean, moreover, the intra-plate seismicity has been very low. However, one great earthquake with Mw 8.1 struck the Balley Islands region on March 25, 1998. This intra-plate earthquake is the largest one ever recorded in the Antarctic Plate [6,7].

[8] compiled the seismicity in and around the Antarctic continent for the first time, and also mentioned the existence of the ice related seismic signals (i.e., icequakes, ice shocks) recorded at several seismological stations. [9] also evaluated the seismicity in the Antarctic from the viewpoint of seismotectonics and neotectonics, by dividing the continent into several tectonic brocks. [10] presented a hypocentral distribution map of Antarctic intra-plate earthquakes in the period of 1900-99 including the records by Global Seismic Network, combined with

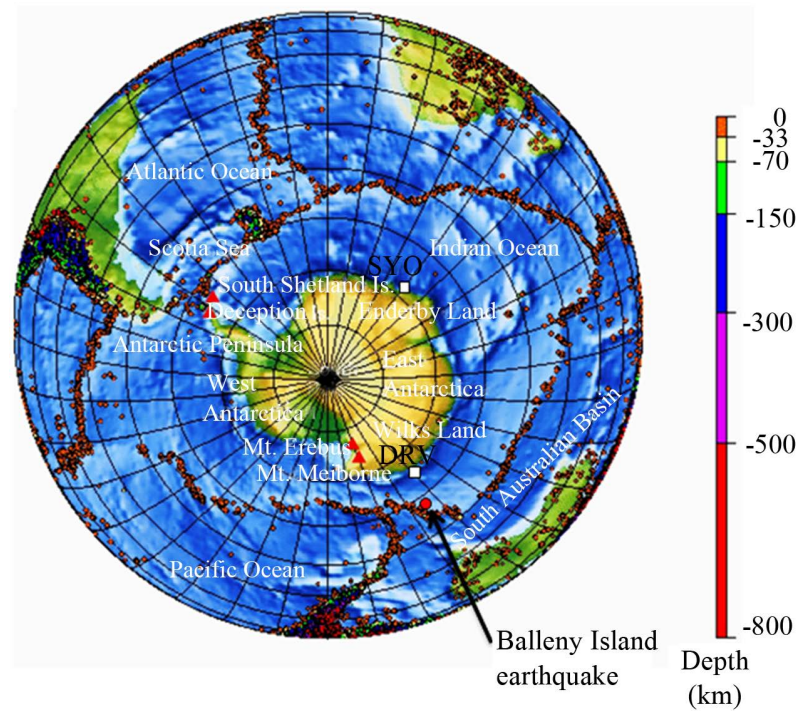

Figure 1. Seismotectonic regions discussed in this paper. Earthquake distribution in and around the Antarctic plate was compiled by NEIC (National Earthquake Information Center) of USGS. Three volcanoes and South Shetland Islands are also shown by solid (red) triangles, and the Balleny Island earthquake is shown by solid (red) circle, respectively. those by permanent Antarctic stations in addition to temporary field stations.

In this paper, seismicity in the Antarctic continent and surrounding ocean is overviewed by using the data from the International Seismological Centre (ISC). Seismicity in terms of each tectonic setting is discussed by being divided into the following five regions: intra-plate low-seismic regions; high-seismic region around the Antarctic Peninsula; the Antarctic Continent aseismic region; lowseismic region at the edge of the Continent; and the volcanic regions.

\section{Antarctic Continent}

A general seismicity map in and around the Antarctic Plate is shown in Figure 1. The earthquake locations are compiled by the National Earthquake Information Center (NEIC) of USGS. The Antarctic continent is roughly divided into two large tectonic provinces; East Antarctica (eastern hemisphere part from the Transantarctic Mountains) and the other younger province; West Antarctica. East Antarctica is characterized by a fragment of Gondwana super-continent, one of the members of adjacent Pre-Cambrian terrains in southern hemisphere (South America, Africa, India and Australia; Figure 1). West Antarctica, on the contrary, is attributed by a chain of many islands beneath the ice sheet of Cenozoic era, including several active volcanoes.

Four earthquakes inside the continental area of Antarctica were reported to the ISC catalog in early stage of Antarctic scientific research. However, except only one event out of the four, no significant earthquakes were located in the continent before the IGY, because neither their locations nor their magnitudes were accurately determined [11]. One event which occurred on June 26, 1968 was located in Coats Land, $20^{\circ} \mathrm{W}, 80^{\circ} \mathrm{S}$ using the initial phase readings of five seismic stations on the Antarctic continent [3]. The magnitude of the event was 4.3 determined by the waveform amplitude of a three-component seismograph at South Pole Station (SPA). This was the first earthquake located instrumentally in the continent using the data of only seismic stations in Antarctica. However, this event was not listed in the ISC catalog. [3] used the data of five stations for hypocenter determination and two of the five stations were Byrd Seismic Array. As the focal depth was determined $1 \mathrm{~km}$ beneath the sea level, the event was considered to be an earthquake in the crust, not an ice-quake.

On the other hand, [4] reported an earthquake near the coast of Oates Land at $70.5^{\circ} \mathrm{S}$ and $161.3^{\circ} \mathrm{E}$ on October 15, 1974. This event was the only shock to be located on the Antarctic continent by international agency by that time. Magnitude of the event was estimated to be 5 and he concluded that the event might be an ice-quake associated with ice movement or cracking. Therefore, there are am- 
biguity to identify the very shallow events near the surface only from the hypocentral information, whether they are tectonic events or the ice related signals.

Regarding the wide inland area of East Antarctica, seismicity in Wilkes Land ("G" in Figures 2 and 3) is found to be one order higher than that in vicinity of Syowa Station $\left(69.0^{\circ} \mathrm{S}, 39.0^{\circ} \mathrm{E}\right)$, the Lüzow-Holm Bay (LHB), East Antarctica [9,12]. Seven earthquakes with $\mathrm{Mb} 4.0$ - 4.9 were located in the coastal area of $100^{\circ}$ $170^{\circ} \mathrm{E}$ and $66^{\circ}-82^{\circ} \mathrm{S}$ in Wilkes Land in 1964-1996. Another nine earthquakes were located in the inland area and two were located offshore. The magnitudes of these eleven earthquakes were not accurately determined. Not only micro-seismic activity, but also small earthquake activity in Wilkes Land and surrounding coasts are higher than that in other area on the East Antarctic continent. The sub-glacial topography in Wilkes Land is characterized by a sub-glacial basin with $1000 \mathrm{~m}$ below sea level in minimum elevation of the bedrock [13]. The maximum thickness of the ice sheet in the area is over $4000 \mathrm{~m}$ and the surface elevation of the ice sheet is mostly over $2000 \mathrm{~m}$. The formation, distribution and stability of these sub-glacial lakes might affect on tectonic processes involving relatively high seismicity in this area.

\section{Southern Ocean}

Seismic activity inside the Antarctic Plate has been known as very few distributions of their epicenters both in ocean and continent areas. As the space distribution and time variations in seismicity around the Antarctic Plate, in particular for the Indian Ocean sector $\left(0^{\circ}\right.$ $160^{\circ} \mathrm{E}, 20^{\circ}-80^{\circ} \mathrm{S}$ ), was previously evaluated and intraplate seismicity was discussed associated with far-field tectonic stress in the oceanic lithosphere [14]. Therefore in this study, a detail hypocentral distribution within the whole Antarctic Plate is investigated by using the data from ISC in 1964-2002. Figure 2 represents the earthquake locations compiled by ISC in the area of $20^{\circ}-80^{\circ} \mathrm{S}$ and every $60^{\circ}$ of longitude. Among the individual $60^{\circ}$ longitude sectors and South Pole area in $80^{\circ}-90^{\circ} \mathrm{S}$, the earthquake activities are divided into 13 regions (from "A" to "M", Table 1). Since the seismic activities are extremely high along the plate boundaries around the Antarctic Plate between the surrounding plates, a criterion of the area for intra-plate was selected very carefully not to include the events associated with the plate boundaries.

\section{Continental Margins}

[10] pointed out the considerable number of intra plate earthquakes in the $90^{\circ}-180^{\circ} \mathrm{E}$ quadrant and divided the earthquakes into two groups as poorly located earthquakes and well located ones. Inside the continental area in Antarctica, seismicitiy is almost very few in " $D$ ”, “ $G$ ” and "M" areas of Figure 2. However, the Wilkes Land ("M" in Figures 2 and 3) had been identified as the most active within the Antarctic continent at IGY period. Poorly located earthquakes were lined from north to south along the $140^{\circ} \mathrm{E}$ longitude [9]. In the earthquake locating area, the Resolution sub-glacial highland, the Adventure sub-glacial trench, and the Belgica sub-glacial highland are existed along the longitudinal direction from east to west [13]. There is a possibility that the poorly located earthquakes were ice-quakes, because the thick ice sheet and complicated sub-glacial topography must cause ice-shocks. Generally the edge of the continent, the coast area, is aseismic region.

Over the past few decades, more seismic observations in polar region have detected local seismicity by both temporary seismic networks and permanent stations. [16] found the majority of seismicity near the Scott Base (SBA, $167^{\circ} \mathrm{E}, 78^{\circ} \mathrm{S}$ ) and Wright Valley area (VNDA, $162^{\circ} \mathrm{E}, 78^{\circ} \mathrm{S}$ ) located along the coast, particularly near large glaciers. They suggested a few generation mechanisms for these events, distinguishable by their focal mechanism and depth: basal sliding of the continental ice sheet, movement of ice streams associated with several scales of glaciers, movement of sea-ice, and tectonic earthquakes.

[17] deployed a local seismic network around the Neumayer Station $\left(08^{\circ} \mathrm{W}, 71^{\circ} \mathrm{S}\right)$, and determined hypocenters of local tectonic events, located along the coast and the mid area of the surrounding bay. A seismic array has been operated more than one decade at the Neumayer Station. Since the deployment of the seismic network/ array, several local events could be detected. Two seismic active regions were figured out at inland area and offshore of the continent. In addition, a broadband seismic network had been developed in the large region between Mawson and Casey stations and inland as far as $75^{\circ} \mathrm{S}$ by Australia [18]. The aim to establish the seismic network is to discover the" seismic structure of the continent under Antarctica (SSCUA)”. Moreover, India has also been carried out seismic observation at the Maitri Station $\left(12^{\circ} \mathrm{E}, 71^{\circ} \mathrm{S}\right)$ since 1997 . The seismic data have already been contributed to earthquake locations by ISC. India also has published "Seismological Bulletin of Maitri Station, Antarctica” in every year [19].

\section{Lützow-Holm Bay}

Once a denser seismic network was established, small/ micro earthquake activities became gradually clear. The LHB area around Japanese Syowa Station, East Antarctica, is one of the area where seismic activity has been well studied since 1980s [20]. Since seismic observations started by a tripartite network in 1987, seismicity for relatively small events became clear in and around Syowa Station. A total of 18 local earthquakes were located 


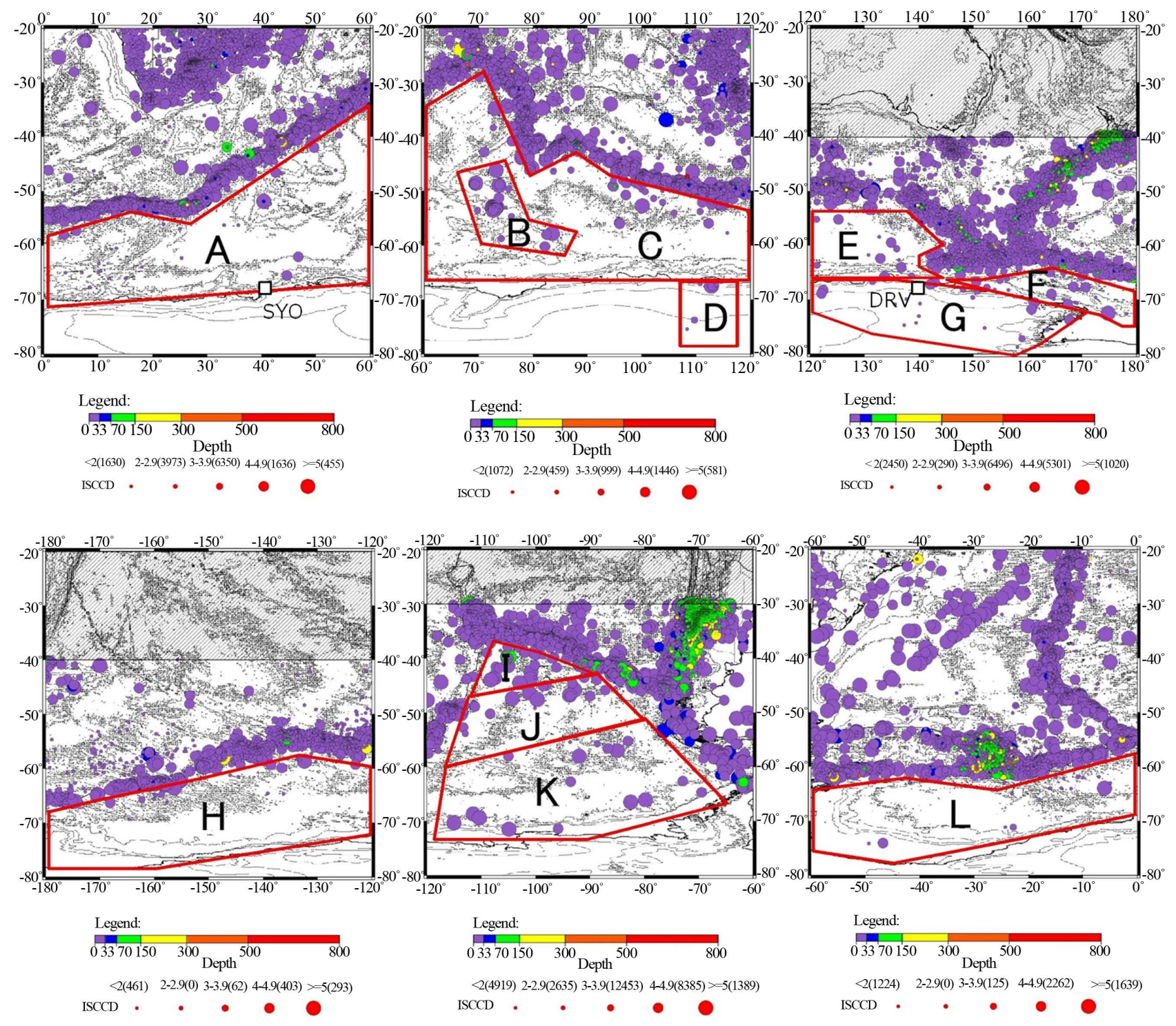

Figure 2. Earthquake locations determined by ISC in $20^{\circ}-80^{\circ} \mathrm{S}$ and every $60^{\circ}$ of longitude. Surrounded areas by solid red lines indicate individual blocks (“A” - " $L$ ”) discussing seismicity in this paper. These areas were classified into Antarctic continent ("D" and "G") and oceanic region within Antarctic Plate (other regions). Numerous denoted in the brackets correspond to magnitude ranges representing the number of included events for each $60^{\circ}$ longitude sector.

during the 15 years in 1987-2003 ([12]; Figure 4).

Characteristic features in time variations of seismic activity are summarized as follows; Seismicity in 19871989: A three-station seismic network was operated around the Syowa Station. Epicenters of ten local earthquakes were determined during these three years. Many different types of earthquakes, such as a main-shock-aftershock, twin earthquake, earthquake swarms, were detected and identified at that time. The seismic activity during this period was higher than that of the following decade. In 1990-1996, nine local earthquakes were recorded with many different types of events. The seismic activity during this period was very low and the magnitudes of the earthquakes ranged from -0.5 to 1.4. One local event was detected in 1997, two events in 1998 and one event in 2001 and 2003, respectively. The low seismic activity continues to the present day in 2004.

The seventeen events were only detected by local seismic network deployed around the LHB, except for the September $1996 \mathrm{Mb}=4.6$ earthquake in the southern Indian Ocean. Almost all the hypocenters were located along the coast, apart from a few on the northern edge of the continental shelf. Local earthquakes in and around Syowa Station were presumably caused by tectonic stress accumulated with crustal uplift after deglaciation [21]. The effect of ice sheet changes may have caused phenomena such as crustal deformation, earthquake occurrence, faulting systems in the shallow part of the lithosphere 


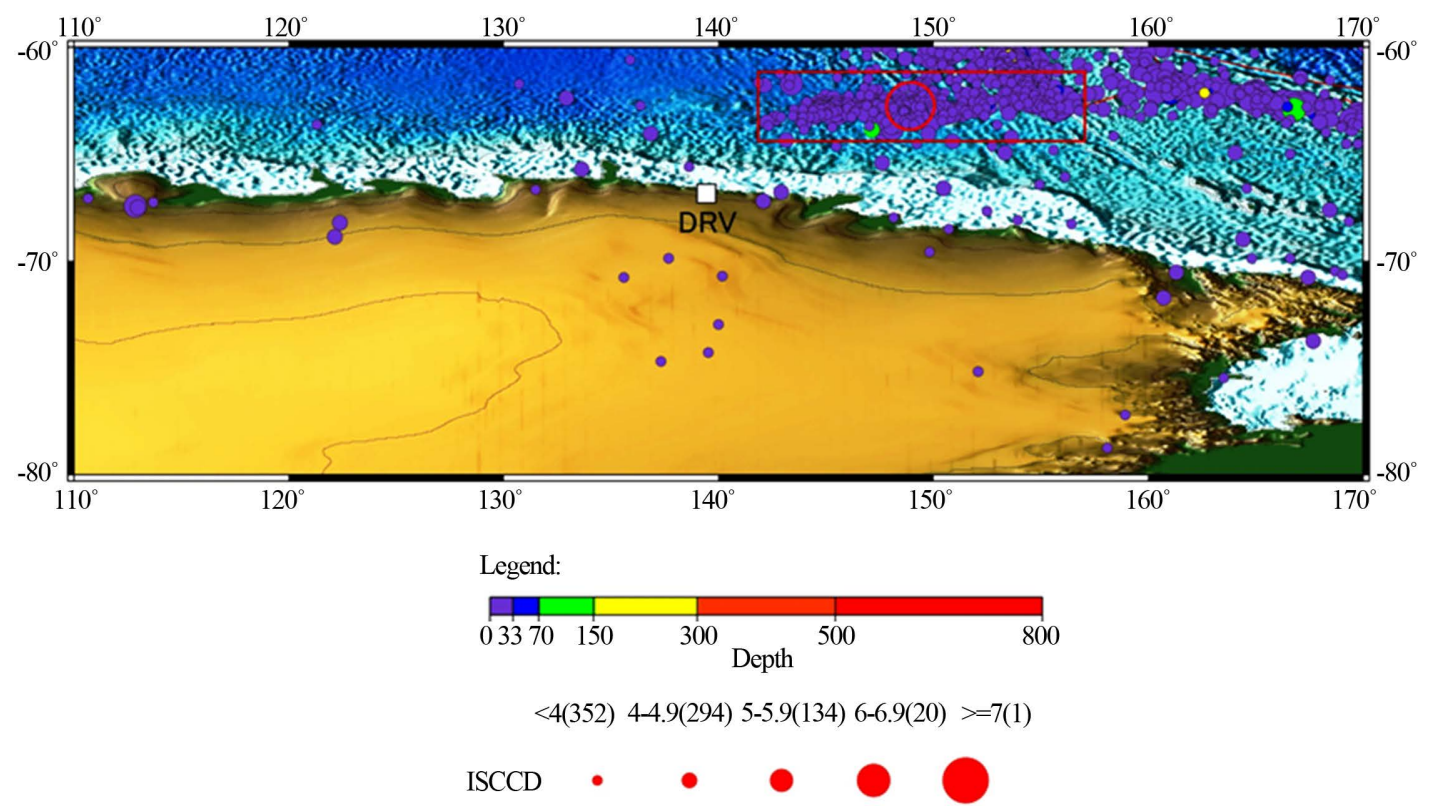

Figure 3. Earthquake locations in $60^{\circ}-80^{\circ} \mathrm{S}$ and $110^{\circ}-170^{\circ} \mathrm{E}$, including both the Wilkes Land and aftershock area (red square) of the March 25, 1998 Balleny Island earthquake $(\mathrm{Mw}=8.1$, red circle). Numerous denoted in the brackets correspond to magnitude ranges representing the number of included events.

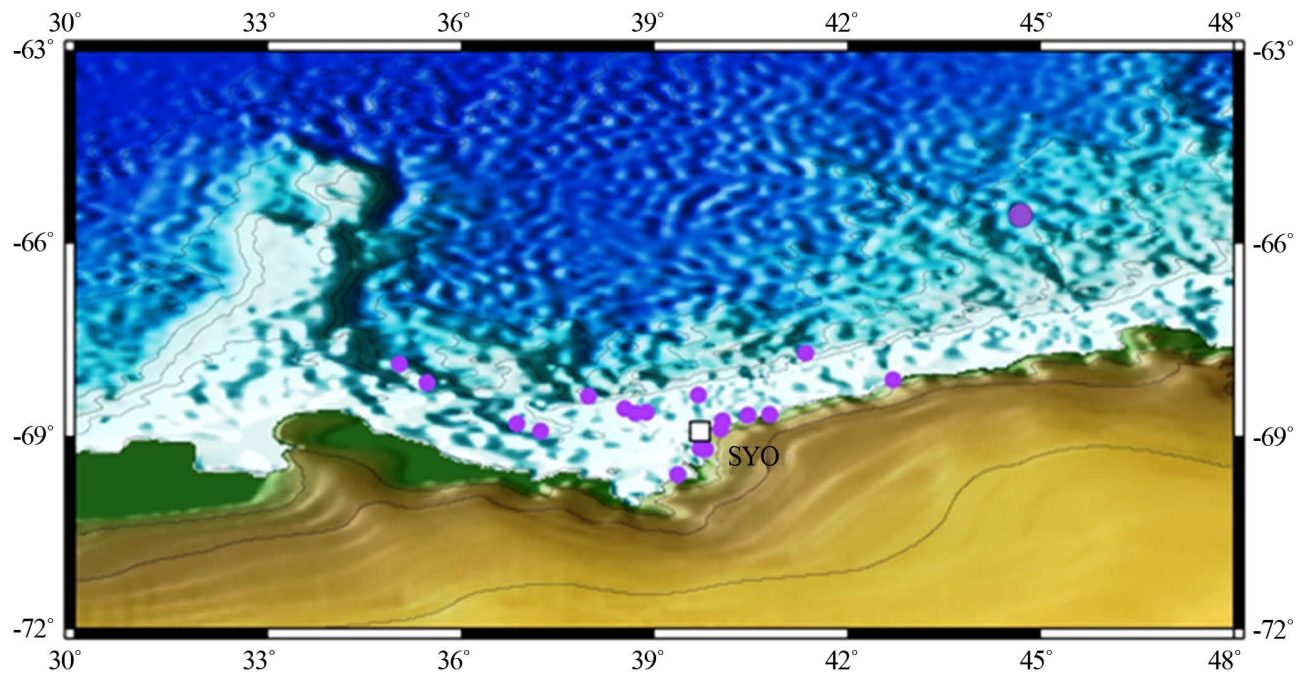

Legend:

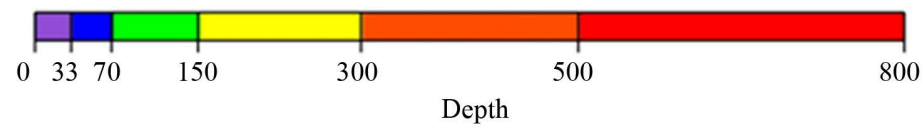

$<4(18) \quad 4-4.9(1) \quad 5-5.9(0) \quad 6-6.9(0) \quad>=7(0)$

ISCCD

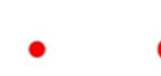

Figure 4. Earthquake locations in and around the Lützow-Holm Bay (LHB), East Antarctica detected at Syowa Station. Total number of 19 events were determined their hypocenters. Numerous denoted in the brackets correspond to magnitude ranges representing the number of included events. 
Table 1. Classification of the Antarctic intra-plate earthquakes in 1964-2002 period compiled by ISC, corresponding the individual blocks in Figure 2.

\begin{tabular}{|c|c|c|c|c|}
\hline Block & LAT & LON & Event number & Comment \\
\hline A & $0^{\circ}-60^{\circ} \mathrm{E}$ & $20^{\circ}-80^{\circ} \mathrm{S}$ & 33 & Ocean \\
\hline B & $60^{\circ}-120^{\circ} \mathrm{E}$ & $20^{\circ}-80^{\circ} \mathrm{S}$ & 58 & $\begin{array}{c}\text { Ocean, } \\
\text { Kerguelen Plateau }\end{array}$ \\
\hline $\mathrm{C}$ & $60^{\circ}-120^{\circ} \mathrm{E}$ & $20^{\circ}-80^{\circ} \mathrm{S}$ & 26 & Ocean \\
\hline $\mathrm{D}$ & $60^{\circ}-120^{\circ} \mathrm{E}$ & $20^{\circ}-80^{\circ} \mathrm{S}$ & 5 & Continent \\
\hline E & $120^{\circ}-180^{\circ} \mathrm{E}$ & $20^{\circ}-80^{\circ} \mathrm{S}$ & 33 & Ocean \\
\hline $\mathrm{F}$ & $120^{\circ}-180^{\circ} \mathrm{E}$ & $20^{\circ}-80^{\circ} \mathrm{S}$ & 26 & Ocean \\
\hline G & $120^{\circ}-180^{\circ} \mathrm{E}$ & $20^{\circ}-80^{\circ} \mathrm{S}$ & 23 & $\begin{array}{l}\text { Continent, } \\
\text { Wilks Land }\end{array}$ \\
\hline $\mathrm{H}$ & $180^{\circ}-120^{\circ} \mathrm{W}$ & $20^{\circ}-80^{\circ} \mathrm{S}$ & 22 & Ocean \\
\hline I & $120^{\circ}-60^{\circ} \mathrm{W}$ & $20^{\circ}-80^{\circ} \mathrm{S}$ & 19 & $\begin{array}{l}\text { Ocean, Easter Is. } \\
\text { Triple Junct. }\end{array}$ \\
\hline $\mathrm{J}$ & $120^{\circ}-60^{\circ} \mathrm{W}$ & $20^{\circ}-80^{\circ} \mathrm{S}$ & 20 & Ocean \\
\hline K & $120^{\circ}-60^{\circ} \mathrm{W}$ & $20^{\circ}-80^{\circ} \mathrm{S}$ & 17 & Ocean \\
\hline $\mathrm{L}$ & $60^{\circ}-0^{\circ} \mathrm{W}$ & $20^{\circ}-80^{\circ} \mathrm{S}$ & 33 & Ocean \\
\hline M & & $80^{\circ}-90^{\circ} \mathrm{S}$ & 8 & $\begin{array}{l}\text { Continent, } \\
\text { South Pole }\end{array}$ \\
\hline
\end{tabular}

beneath Antarctica [16]. Several of these events, moreover, could be large ice-quakes associated with the sea-ice dynamics around the LHB or in the Southern Ocean.

\section{Antarctic Peninsula}

The epicentral locations in the Antarctic Peninsula of $20^{\circ}$ $-80^{\circ} \mathrm{W}, 50^{\circ}-70^{\circ} \mathrm{S}$ are shown in Figure 5, on the basis of the ISC data catalog in 1964-2002. The earthquake activity in this region is the highest in Antarctic including active volcanic areas in Deception Island, together with subduction zone in the Bransfield Strait. The focal depths of the earthquakes are mostly shallower than $40 \mathrm{~km}$. During two decades in 1971-1989, only four earthquakes occurred with focal depths between 40 and $100 \mathrm{~km}$ [9]. One big event occurred on Feb. 8, 1971, for which Mb and Ms were determined to be 6.3 and 7.0 respectively. In addition that the event is the largest earthquake recorded in the region, the only recorded event with magnitude lager than 7.0 in Antarctica. This earthquake was the first tectonic earthquake to be felt in the Antarctic, observed at the Farady Station $\left(65^{\circ} \mathrm{S}, 64^{\circ} \mathrm{W}\right)$ of United Kingdom [22].

According to the report of seismic events recorded at King Sejoung Station $\left(60^{\circ} \mathrm{S}, 59^{\circ} \mathrm{W}\right)$ of South Korea, King George Island of the South Shetland Islands, some earthquake swarms occurred around Bridgeman Island [23]. [24] evaluate these earthquake swarms in view from physical volcanology. The earthquake swarms appeared to represent typical volcanic earthquake waveforms. The earthquake swarm might be originated around ORCA Sea Mount about $20 \mathrm{~km}$ southeast of King Sejoung Station. Many earthquakes are located in the back-arc area, either on large submarine volcanoes or rifting region along the center of the Bransfield Strait. Earthquakes concentrated around ORCA Sea Mount and Bridgeman Island. These earthquake locations indicate that the seismicity is associated with active volcanism rifting, non active subduction systems.

[25] deployed seven continuously recording broadband seismometers in the South Shetland Islands region during 1997 and 1998. High level of local seismicity was identified in the first 15 months. About 90 earthquakes with magnitude mb 2 - 4 were located. Many earthquakes with 10 - $30 \mathrm{~km}$ depth are located in the forearc region extending from the South Shetland Trench axis toward and beneath the South Shetland Islands. The earthquake locations suggest active convergence along the South Shetland subduction zone, however, there is no significant subduction zone extending into mantle.

\section{Volcanic Regions}

Seismic observations in volcanic regions have been carried out only three volcanoes as shown in Figure 1. Eruptions were recognized at Deception Island $\left(63^{\circ} \mathrm{S}, 61^{\circ} \mathrm{W}\right)$ and Mount Erebus $\left(78^{\circ} \mathrm{S}, 167^{\circ} \mathrm{E}, 3974 \mathrm{~m}\right)$, on the contrary, no eruption was recognized at Mount Melbourne $\left(74^{\circ} \mathrm{S}, 165^{\circ} \mathrm{E}, 2732 \mathrm{~m}\right)$. The first felt shock in the Antarctic was the magnitude 4.7 earthquake accompanied by the volcanic eruptions of Deception Island on December 4, 1967 [22]. This eruption was the first recognized explosion of Deception Island by humankind. The buildings of the stations on Deception Island were destroyed by the eruptions and all members in the stations of Argentina, Chile and the UK evacuated safely after the eruption. All of the stations at Deception Island have been closed since that time.

Since 1980's Spanish established a summer stations at Deception Island and started geophysical research on Deception Volcano. [26] have carried out seismic observations with five stations during the austral summer since 1987, and observed approximately 1000 local events per month. Earthquake locations seem to be concentrated along the NE-SW direction crossing the central part of the island. In the 1991-92 survey, the seismic activity was significantly increased with total number of recorded earthquakes more than 700 , an extending of the areas with geothermal anomalies and major activity of the fumaroles. The seismic activity was low in 1992-93 and 1993-94 surveys, and no other volcanic anomalies were observed. In the 1994-95 survey, a new increase of seismic activity was recorded with more than 800 seismic events [27]. 

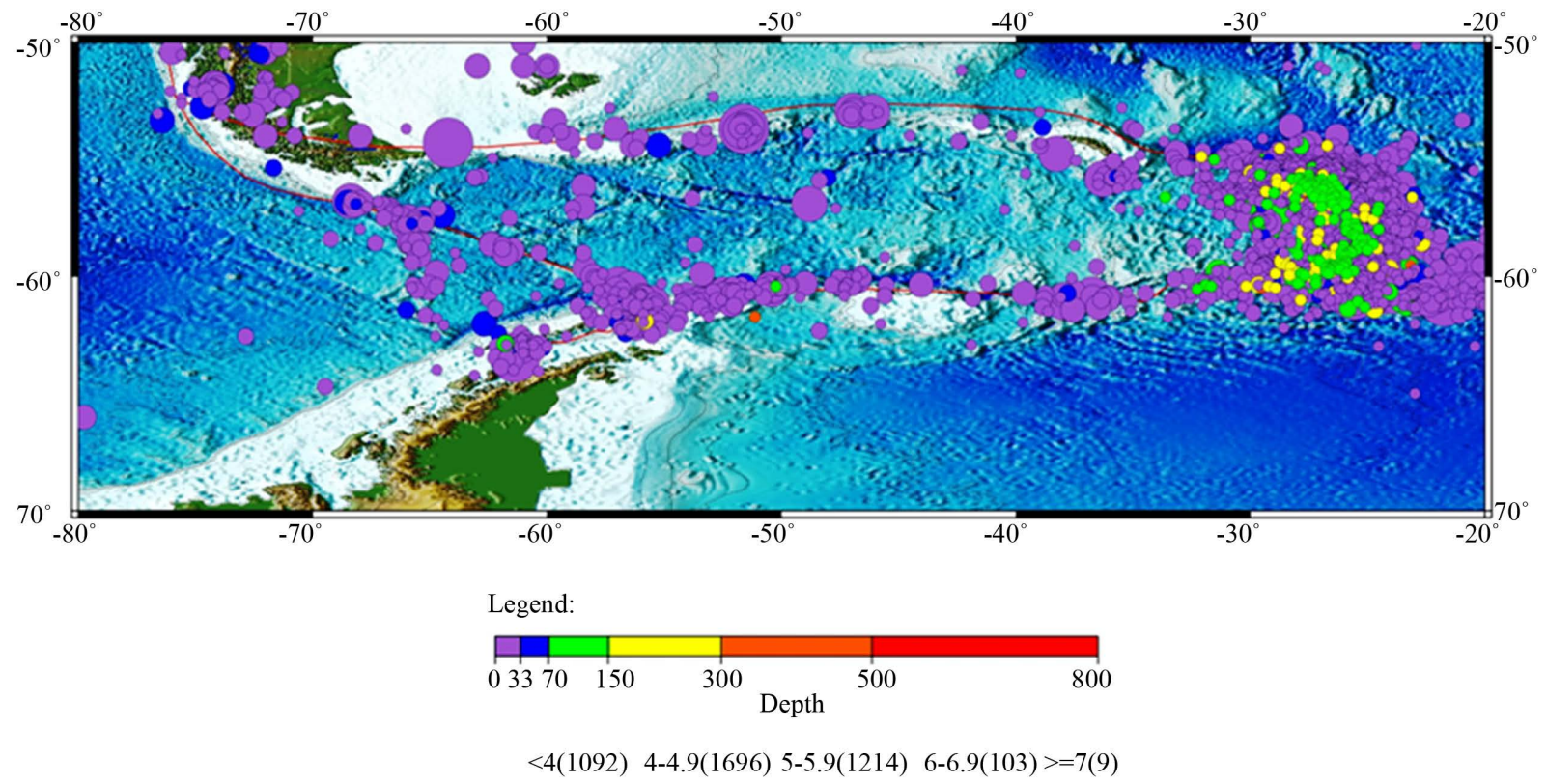

ISCCD

Figure 5. Earthquake location around Antarctic Peninsula. Numerous denoted in the brackets correspond to magnitude ranges representing the number of included events.

Seismic observations by radio-telemetry continued in the summit area and on the slope of Erebus Volcano on Ross Island by the international cooperation among Japan, New Zealand and US during 1981-90 [28]. Seismic activity around Mount Erebus became clear and remarkable change of seismic activity were recognized before and after the new phase of volcanic activity started on September 13, 1984. It was characterized by larger and more frequent strombolian eruptions. Significant changes in seismicity within Ross Island and Mount Erebus were recognized both before and after the increased eruptive activity. The seismic activity of Mount Erebus in 19801990 is divided into the following four stages: 1) normal high activity, 2) preceding the new phase, 3) new phase in volcanic activity and 4) low seismic activity. These stages suggest a general pattern of volcanic activity and give a fundamental information concerning production of volcanic eruption.

US scientists have still been carrying on the monitor of seismic activity around Mount Erebus [29]. A research program on physical volcanology has been conducted around Mount Melbourne by Italian scientists since the end of the 1980's. Four seismic stations were installed on Mount Melbourne since 1990 and many local earthquakes have been reported together with other geophysical data [30]. Local seismicity clustered along the eastern flank of Mount Melbourne, possibly in spatial association with the local north-south magnetic trend. One event occurred on December 10, 1990 is the largest earthquake with magnitude 1.9 around Mount Melbourune [31].

\section{Ice-Quakes, Glacial Earthquakes}

Seismic signals involving ice-related phenomena are called "ice-quakes (ice-shocks for smaller ones)", and are most frequently reported in association with glacially related mass movements of ice-sheets, or with sea-ice, tidecracks and icebergs in the other polar areas [32,12]. The so-called "ice-micity" detected around the Bransfield Strait and Drake Passage by a local network of hydrophone arrays in 2006-2007 illustrate the dynamic behavior of sea ice in the Bransfield and Antarctic Peninsula regions [33].

Dynamics of sea-ice and icebergs also affect on the seismic signals. For example, a large volume of sea ice was discharged from LHB during the 1997 austral winter, and clearly imaged by the NOAA satellite. The broadband seismographs at Syowa Station recorded distinct waveforms associated with the discharge events [34]. The long-duration sea-ice tremors had very distinct spectral characteristics that distinguished them clearly from ordinary teleseismic and/or local tectonic events. Several sequences of harmonic over-toned signals, presumably associated with the merging of multiple ice volumes, appeared on the seismic signals [34]. The characteristic signals also represent the surge events that seem more closely related to the break-up process of the sea-ice mass volume. Both kinds of cryoseismic waves occurred continuously for few hours, and repeated themselves 
several times within a few days during late July, 1997. Identification of the exact sources that produced these characteristic signals has not yet been completed, and theoretical modeling will most likely be required to explain the physical processes.

Similar cryoseismic phenomena have also been reported around the Ross Sea region (MacAyeal et al., 2009), the marginal sea of the Antarctic Peninsula [33], as well as the continental margin of Dronning Maud Land [17]. In particular, iceberg-originated harmonic tremor emanating from tabular icebergs was observed by both seismo-acoustic and local broadband seismic signals [35]. The tremor signals consisted of extended episodes of stick-slip ice-quakes generated when the ice-cliff edges of two tabular icebergs rubbed together during glancing, "strike-slip" type iceberg collisions. Source mechanisms of such harmonic tremors might provide useful information for the study of iceberg behavior, and a possible method for remotely monitoring iceberg activity.

In addition to the short-period cryoseismic signals mentioned above, a new class of seismic events associated with melting of large ice cap was discovered in particular around Greenland [36,37]. These large events were called "glacial earthquakes", generating long-period ( $\mathrm{T}>25$ s) surface waves equivalent in strength to those radiated by standard magnitude five earthquakes, and were observable worldwide. The glacial earthquakes radiated little high-frequency energy, which explains why they were not detected or located by traditional earthquake-monitoring systems. These events are two magnitude units larger than previously reported seismic phenomena associated with glaciers, a size difference corresponding to a factor of 1000 in a seismic moment.

\section{Discussion}

For many decades, the Antarctic continent and surrounding area have been believed as aseismic. Several earthquakes were found to be located in the Antarctic continent since IGY, as mentioned in this paper. It became general knowledge that there are small earthquake activities detected in the Antarctic Continent even though the activity itself is not so high as other continents. However the event of which magnitude lager than 5 is not detected during last four decades. The number of tectonic earthquakes located in the Antarctic has increased according to the development of Global Seismic Networks and local seismic arrays. The most of the tectonic earthquakes along the coast of the Antarctic continent are caused by tectonic stress accumulated by crustal deformation after deglaciation.

The micro-earthquake activity around Syowa Station as mentioned the previous section might be a typical activity on the coastal area of the Antarctic continent where crustal uplift after deglaciation is now going on. As sei- smological observation like the local array deployment around Syowa Station have been developing at several stations in the coastal area, high activity of micro-earthquakes will be detected on the continental margin of Antarctica. If the other geophysical observations such as tide gauges, gravimeters and GPS have been carried out at coastal stations, the relation between micro-earthquake activity and crustal movement will become clear.

Around continental area in East Antarctica from $90^{\circ}$ $180^{\circ} \mathrm{E}$, in generally, seismicity is low in an average. As already treated in Chapter 2, the Wilkes Land, in contrast, has been identified as the most tectonically active region within the Antarctic. It is also noticed that there is a significant number of sub-glacial lakes in this area, then can be considered a relation to produce the occurrence of local seismic activities. The formation, distribution and stability of sub-glacial lakes could give rise to the fundamental question how the tectonic processes control the existence of the lakes [38]. The poorly located earthquakes, accordingly, could be a kind of large ice-quakes, because complicated sub-glacial topography with overlying ice-sheet in this area may efficiently cause ice related seismic phenomena.

A complexity of the surface bedrock structure of Wilkes Land, moreover, might be influenced by tectonically weakened upper crust along with the present mobile belts, forced by the Tasmania micro plate $[7,12]$. The aftershock area of the large Balleny Island Earthquake in the Antarctic Oceanic Plate appears to be continued with the continental area of Wilkes Land (Figure 3). It might be supposed that the large earthquakes generate in this area, by assuming thermal stress of the young lithosphere, associated with unusual deformation due to Macquarie triple junction [39]. Recently several intra-plate earthquakes became to be located in the southern ocean. In contrast, there is a possibility that some earthquakes off of the Antarctic Plate are also caused by crustal deformation and tectonic stress involving deglaciation [6]. It is strongly suggested that the effect of volume and shape change of ice sheet causes some phenomena in the crust and upper mantle such as crustal uplift, earthquake occurrence, lithospheric deformation.

\section{Conclusion}

Seismicity in the Antarctic and surrounding ocean is evaluated based on the compiled data in 1964-2002 by International Seismological Centre. The Antarctic continent and surrounding ocean were believed to be one of the aseismic regions of the Earth for many decades. However, according to the development of Global Seismic Networks and local seismic arrays, the number of tectonic earthquakes detected in and around the Antarctic continent has increased. The total of 13 seismicity areas were classified into the Antarctic continent (three areas) 
and oceanic regions within Antarctic Plate (the other 10 areas). Generally, seismic activity in the continental areas is very low; few small earthquakes located. The Wilkes Land is the most active area in the Antarctic continent; several small earthquakes were detected during these four decades. In the ocean area, in contrast, the seismic activity in the area of $120^{\circ}-60^{\circ} \mathrm{W}$ sector is three times larger than that in the other areas. This evidence is considered to be involved in a stress concentration toward the Easter Island Triple Junction among Antarctic Plate, Pacific Plate and Nazuca micro-Plate. Three volcanic areas, Deception Island, Mt. Erebus and Mt. Melbourn, are also high seismic activity areas. Finally, there are a lot of undefined origin events which include both tectonic earthquakes involving deglaciation, as well as cryoseismic signals associated with variations in the surface environment.

\section{Acknowledgements}

The authors express their sincere thankfulness to Ms. A. Ibaraki of NIPR, for her great efforts in re-scaling the Syowa Station data in last two decades. The authors also appreciate to Profs. K. Shibuya, K. Doi, Y. Nogi and Y. Aoyama of NIPR for their valuable advice and discussions for manuscript. The authors would express their sincere appreciation to the International Seismological Centre (ISC), for the utilization of the compiled data.

\section{REFERENCES}

[1] B. Gutenberg and C. F. Richter, "Seismicity of the Earth and Associated Phenomena,” Princeton University Press, Princeton, 1954.

[2] C. F. Richter, "Elementary Seismology,” W. H. Freeman (Ed.), San Francisco, 1958, p. 768.

[3] K. Kaminuma and M. Ishida, "Earthquake Activity in Antarctica,” Antarctica Record, Vol. 42, 1971, pp. 53-60.

[4] R. D. Adams, "Source Properties of the Oates Land Earthquake,” In: C. Craddock, Ed., Antarctic Geoscience, The University of Wisconsin Press, Wisconsin, 1982, pp. 955958.

[5] A. C. Johonstone, "Suppression of Earthquakes by Large Continental Ice Sheets,” Nature, Vol. 330, 1987, pp. 467469. http://dx.doi.org/10.1038/330467a0

[6] S. Tsuboi, M. Kikuchi, Y. Yamanaka and M. Kanao, "The March 25, 1998 Antarctic Earthquake: Great Earthquake Caused by Postglacial Rebound," Earth Planets Space, Vol. 52, 2000, pp. 133-136.

[7] T. Himeno, M. Kanao and Y. Ogata, "Statistical Analysis of Seismicity in a Wide Region around the $1998 \mathrm{Mw} 8.1$ Balleny Islands Earthquake in the Antarctic Plate,” Polar Science, Vol. 5, No. 4, 2011, pp. 421-431. http://dx.doi.org/10.1016/j.polar.2011.08.002

[8] K. Kaminuma, "Seismic Activity in and around Antarctic Continent,” Terra Antartica, Vol. 1, 1994, pp. 423-426.
[9] K. Kaminuma, "A Revaluation of the Seismicity in the Antarctic,” Polar Geoscience, Vol. 13, 2000, pp. 145157.

[10] A. M. Reading, "Antarctic Seismicity and Neotectonics," In: J. A. Gamble, et al., Eds., Antarctica at the Close of a Millennium, The Royal Society of New Zealand Bullutin, Wellington, Vol. 35, 2002, pp. 479-484.

[11] R. D. Adams, A. A. Hughes and B. M. Zhang, "A Confirmed Earthquake in Continental Antarctica," Geophysical Journal International, Vol. 81, No. 2, 1985, pp. 489492. http://dx.doi.org/10.1111/j.1365-246X.1985.tb06416.x

[12] M. Kanao and K. Kaminuma, "Seismic Activity Associated with Surface Environmental Changes of the Earth System, around Syowa Station, East Antarctica,” In: D. K. Futterer, et al., Eds., Antarctica: Contributions to Global Earth Sciences, Springer-Verlag, Berlin, Heidelberg, New York, 2006, pp. 361-368. http://dx.doi.org/10.1007/3-540-32934-X_45

[13] D. J. Drewry, “Antarctica: Glaciological and Geophysical Folio, 9 Sheets,” Scottish Polar Research Institute, University of Cambridge, Cambridge, 1983.

[14] M. Kanao, Y. Nogi and S. Tsuboi, "Spacial Distribution and Time Variation in Seismicity around Antarctic Plate -Indian Ocean,” Polar Geoscience, Vol. 19, 2006, pp. 202-223.

[15] D. L. Anderson, “Superplumes or Supercontinents?” Geology, Vol. 22, No. 1, 1994, pp. 39-42.

http://dx.doi.org/10.1130/0091-7613(1994)022<0039:SO $\mathrm{S}>2.3 . \mathrm{CO} ; 2$

[16] S. Bannister and B. L. N. Kennett, "Seismic Activity in the Transantarctic Mountains-Results from a Broadband Array Deployment,” Terra Antarctica, Vol. 9, 2002, pp. 41-46.

[17] C. Muller and A. Eckstaller, "Local Seismicity Detected by the Neumayer Seismological Network, Dronning Maud Land, Antarctica: Tectonic Earthquakes and Ice-Related Seismic Phenomena," IX International Symposium on Antarctic Earth Science Programme and Abstracts, Potsudam, 2003, p. 236.

[18] A. M. Reading, "On Seismic Strain-Release within the Antarctic Plate,” In: D. K. Futterer, et al., Eds., Antarctica: Contributions to Global Earth Sciences, SpringerVerlag, Berlin, Heidelberg, New York, 2006, pp. 351-356. http://dx.doi.org/10.1007/3-540-32934-X_43

[19] G. B. N. Chander, S. V. R. Ramachandra Rao, G. S. Srinivas, E. C. Malaimani and N. R. Kumar, "Seismological Bulletin of Maitri Station, Antarctica, 2002,” National Geophysical Research Institute, 2003, pp. 1-71.

[20] K. Kaminuma and J. Akamatsu, "Intermittent MicroSeismic Activity in the Vicinity of Syowa Station, East Antarctica,” In: Y. Yoshida et al. (Eds.), Recent Progress in Antarctic Earth Science, Terra Science Publication, Tokyo, 1992, pp. 493-497.

[21] K. Kaminuma and M. Kanao, "Local Seismicity and Crustal Uplift around Syowa Station, Antarctica,” Korean Journal of Polar Research, Vol. 10, 1999, pp. 103-107.

[22] K. Kaminuma, "Seismicity around the Antarctic Peninsu- 
la,” Polar Geoscience, Vol. 8, 1995, pp. 35-42.

[23] Y. K. Jin, D. K. Lee, S. H. Nam, Y. Kim and K. J. Kim, "Seismic Observation at King Sejong Station, Antarctic Peninsula,” Terra Antartica, Vol. 5, 1998, pp. 729-736.

[24] K. Kaminuma, "A Possibility of Earthquake Swarms around ORCA Sea Mount in the Bransfield Strait, the Antarctic,” In: Y. Kim and B. K. Khim, Eds., Proceedings of the Joint International Seminar: Recent Interests on Antarctic Earth Sciences of Korea and Japan, 2001, pp. 23-34.

[25] S. D. Robertoson, D. A Wiens, P. J. Shore, G. P. Smith and E. Vera, "Seismicity and Tectonics of the South Shetland Islands and Bransfield Strait from the SEPA Broadband Seismograph Deployment," In: J. A. Gamble et al., Eds., Antarctica at the Close of a Millennium, The Royal Society of New Zealand Bullutin, Wellington, Vol. 35, 2002, pp. 549-554.

[26] J. Vila, R. Ortiz, A. M. Correig and A. Garcia, "Seismic Activity on Deception Island,” In: Y. Yoshida et al., Eds., Recent Progress in Antarctic Earth Science, Terra Science Publication, Tokyo, 1992, pp. 449-456.

[27] R. Ortiz, A. Garcia, A. Aparicio, I. Branco A. Felpeto, R. Rey Del, M. T. Villegas, J. M. Ibanez, J. Morales, E. Pezzo Del, J. C. Olmedillas, M. Astiz, J. Vila, M. Ramos, J. G. Viramonte, C. Risso and A. Caselli, "Monitoring of the Volcanic Activity of Deception Island, South Shetland Islands, Antarctica (1986-1995),” In: C. A. Ricci, Ed., The Antarctic Region: Geological Evolution and Processes, Terra Antartica Publication, Siena, 1997, pp. 10711076.

[28] K. Kaminuma and R. R. Dibble, "Seismic Activity of Mount Erebus 1981-1988,” Polar Geoscience, Vol. 4, 1990, pp. 142-148.

[29] R. Aster, W. McIntosh, P. Kyle, R. Esser, B. Bartel, N. Dunbar, B. Johns, J. Johnson, R. Karstens, C. Kurnik, M. McGowan, S. McNamara, C. Meertens, B. Pauly, M. Richmond and M. Ruiz, "Real-Time Data Received from Mount Erebus,” EOS Transactions, Vol. 85, No. 10, 2004, p. 99. http://dx.doi.org/10.1029/2004EO100001

[30] A. Banaccorso, S. Gambino and E. Privitera, “A Geophysical to the Dynamics of Mt. Melbourne (Northern Victoria Land, Antarctica),” In: C. A. Ricci, Ed., The Antarctic Region: Geological Evolution and Processes, Terra Antartica Publication, Siena, 1997, pp. 531-538.

[31] E. Armadillo, A. Bonaccorso, E. Bozzo, G. Caneva, A.
Capra, G. Falzone, F. Ferraccioli, S. Gandolfi, F. Mancini, E. Privitera and L. Vittuari, "Geophysical Features of the Mt. Melbourne Area, Antarctica, and Preliminary Results from the Integrated Network for Monitoring the Volcano," In: J. A. Gamble et al., Eds., Antarctica at the Close of a Millennium, The Royal Society of New Zealand Bulletin, Wellington, Vol. 35, 2002, pp. 571-577.

[32] S. Anandakrishnan and R. B. Alley, "Tidal Forcing of Basal Seismicity of Ice Stream C, West Antarctica, Observed Far Inland,” Journal of Geophysical Research, Vol. 102, No. B7, 1997, pp. 15183-15196. http://dx.doi.org/10.1029/97JB01073

[33] R. P. Dziak, M. Parlk, W. S. Lee, H. Matsumoto, D. R. Bohnenstiehl and J. H. Haxel, "Tectono-Magmatic Activity and Ice Dynamics in the Bransfield Strait Back-Arc Basin, Antarctica,” The 16th International Symposium on Polar Science, Incheon, 2009, pp. 59-68.

[34] M. Kanao, A. Maggi, Y. Ishihara, M.-Y. Yamamoto, K. Nawa, A. Yamada, T. Wilson, T. Himeno, G. Toyokuni, S. Tsuboi, Y. Tono and K. Anderson, "Interaction on Seismic Waves between Atmosphere-Ocean-Cryosphere and Geosphere in Polar Region,” In: M. Kanao et al., Eds., Seismic Waves-Research and Analysis, InTech. Publisher, Rijeka, 2012, pp. 1-20. http://dx.doi.org/10.5772/1400

[35] D. MacAyeal, E. Okal, R. Aster and J. Bassis, "Seismic Observations of Glaciogenic Ocean Waves (Micro-Tsunamis) on Icebergs and Ice Shelves,” Journal of Glaciology, Vol. 55, No. 190, 2009, pp. 193-206. http://dx.doi.org/10.3189/002214309788608679

[36] G. Ekström, M. Nettles and V. C. Tsai, "Seasonality and Increasing Frequency of Greenland Glacial Earthquakes,” Science, Vol. 311, No. 5768, 2006, pp. 1756-1758. http://dx.doi.org/10.1126/science.1122112

[37] M. Nettles and G. Ekström, "Glacial Earthquakes in Greenland and Antarctica," Annual Review of Earth and Planetary Sciences, Vol. 38, 2010, pp. 467-491. http://dx.doi.org/10.1146/annurev-earth-040809-152414

[38] T. Wilson and R. Bell, "Earth Structure and Geodynamics at the Poles," Understanding Earth's Polar Challenges: International Polar Year 2007-2008, 2011, pp. 273-292.

[39] M. Nettles, T. C. Wallace and S. L. Beck, “The March 25, 1998 Antarctic Plate Earthquake,” Geophysical Research Letters, Vol. 26, No. 14, 1999, pp. 2097-2100. http://dx.doi.org/10.1029/1999GL900387 